\title{
Digestive and metabolic adaptations of ruminants to undernutrition, and consequences on reproduction
}

\author{
Yves Chilliard*, François Bocquier, Michel Doreau
}

Laboratoire sous-nutrition des ruminants, Inra, Theix, 63122 Saint-Genès-Champanelle, France

(Received 12 February 1998; accepted 2 March 1998)

\begin{abstract}
In response to undernutrition, short- (days) and medium-term (weeks) adaptations are more pronounced for splanchnic organs than for other tissues. For the latter, the long-term response involves a sequential mobilization (fat $>$ muscle $>$ bone) with relative priorities differing among anatomical sites. Among chemical components, the body lipids are extensively used (up to $80 \%$ ) in underfed animals, while the range of protein utilization is limited (up to $15-20 \%$ ). The decrease in energy expenditure during undernutrition is mostly due to a short- and medium-term decrease in feeding activity, and in the mass and activity of splanchnic tissues. In the long-term, energy expenditure and tissue masses decrease concomitantly, but there does not appear to be a significant decrease in expenditure per unit tissue weight. Nitrogen losses decrease in response to decline in nitrogen fluxes and also due to sparing by renal activities and sometimes by urea recycling. However, ruminants do not seem to be able to compensate for a low level of intake (below maintenance) by an increase in digestive efficiency. Numerous hormones (insulin, growth hormone, insulin-like growth factor I, catecholamines, thyroid hormones, cortisol, leptin, etc.) are involved in the changes during undernutrition of nutrient fluxes between tissues, either through control of synthesis and/or degradation in peripheral tissues (adipose tissue and muscle), or through hepatic conversions of substrates (gluconeogenesis, ureagenesis and ketogenesis), in order to maintain the constancy of the internal environment (homeostasis) and/or to sustain productive functions (teleophoresis). However, reproductive process may be blocked in underfed animals. (C) Inra/Elsevier, Paris
\end{abstract}

body reserves / digestion / hormones / metabolism / reproduction / ruminants / undernutrition

Résumé - Adaptations digestives et métaboliques des ruminants à la sous-nutrition. Conséquences sur la reproduction. En réponse à une sous-nutrition, les adaptations à court terme (jours) ou à moyen terme (semaines) sont plus importantes pour les tissus splanchniques que

\footnotetext{
* Correspondence and reprints

E-mail: chilliar@clermont.inra.fr
} 
pour les autres tissus. On observe à long terme une mobilisation tissulaire séquentielle (gras $>$ muscle $>$ os), avec des priorités variables entre sites anatomiques. Parmi les constituants chimiques, les lipides corporels sont largement utilisés (jusqu'à $80 \%$ ) chez les animaux sous-nutris, alors que les protéines corporelles sont moins sollicitées (jusqu'à 15-20\%). La diminution de la dépense énergétique pendant la sous-nutrition est principalement due, à court et moyen terme, à des réductions des activités alimentaires et de la masse et de l'activité des tissus splanchniques. A long terme, la dépense énergétique diminue parallèlement à celle de la masse corporelle, et il ne semble pas y avoir de diminution significative de la dépense par gramme de tissu. La dépense azotée est diminuée parallèlement à la réduction des flux d'azote, mais également par une économie au niveau du rein et parfois par un recyclage de l'urée. Toutefois, les ruminants ne semblent pas pouvoir compenser une diminution du niveau d'ingestion (en dessous de l'entretien) par une meilleure efficacité digestive. De nombreuses hormones (insuline, hormone de croissance, IGF-I, catécholamines, hormones thyroïdiennes, cortisol, leptine,..) sont impliquées dans les modifications des flux de nutriments entre tissus causées par la sous-nutrition. Elles agissent en régulant soit les synthèses, soit les dégradations au niveau des tissus périphériques (tissu adipeux, muscle), ou les transformations hépatiques des substrats (pour la néoglucogenèse, l'uréogenèse et la cétogenèse), pour maintenir la constance du milieu intérieur (homéostasie) ou pour soutenir des fonctions productives (téléophorèse). Toutefois, la fonction de reproduction peut être bloquée par la sous-nutrition. (C) Inra/Elsevier, Paris

\section{digestion / hormones / métabolisme / reproduction / réserves corporelles / ruminants / sous-nutrition}

\section{INTRODUCTION}

The ability of ruminants to cope with periods of food shortage is the result of a long evolutionary process in natural conditions where food availability seasonally fluctuates. Most domesticated ruminants are subject to major constraints, some of which are reinforced by man who utilizes their adaptability for economic or husbandry reasons. For example, beef cows are often underfed in winter, when the availability of conserved forages is limited; they restore their body reserves at pasture. Group-fed ewes can also be underfed when food supply is given according to the average requirements of the group, owing to variability in their requirements. Besides this, physiological underfeeding is the general rule of high producing dairy cows in early lactation. However, the most drastic problems of underfeeding occur because of unfavourable climatic conditions which limit forage growth and thus availability, especially in arid and tropical areas. In such situations, all the coping mechanisms and especially body fat and protein mobilisation strategies are obviously of considerable importance in determining animal productivity and, in many instances, survival.

This paper describes the adaptative mechanisms of digestion and metabolism in underfed ruminants. The central role of body reserves is considered together with variations in maintenance $(\mathrm{M})$ expenditures in non-productive animals. In productive animals, interactions between nutrition and physiological demand for reproduction, pregnancy, lactation or growth have been used to highlight adaptative mechanisms involved when food supply is inadequate. Indeed, even if food supply is abundant and constant, changes in nutrient demand may also create unbalanced nutritional situations, thus leading to a distinction between absolute and relative inadequacy of food supply. We have also made distinctions between different time-scales in adaptations to food supply: 
short-term adaptation (d) due to diurnal feeding frequency or from day-to-day changes in food availability; medium-term adaptations that appear within a few weeks; and long-term adaptations that require animals to progress towards a new equilibrium in a different nutritional and/or physiological context.

\section{VARIATIONS IN BODY WEIGHT AND COMPOSITION}

When ruminants are underfed, shortterm decreases in live weight $(\mathrm{LW})$ are due mainly to gut fill variations ( -4 to $-5 \mathrm{~kg} \mathrm{LW}$ per $\mathrm{kg}$ decrease in dry matter intake). When intake is stabilized (medium term), however, LW variations mostly reflect changes in organ and tissue masses. In the case of severe undernutrition of Lacaune ewes $(0.34-0.40 \mathrm{M})$, LW decreased rapidly (ca $-15 \%$ ) in the short term (1-2 weeks) and then linearly at a slower rate for at least $60-80 \mathrm{~d}$ until $-30 \%$ ([7]; figure 1). An even greater loss (42\%) was obtained over a 62-d fasting in fattailed Barbary sheep that was then restored totally within $70 \mathrm{~d}$ of refeeding [69].

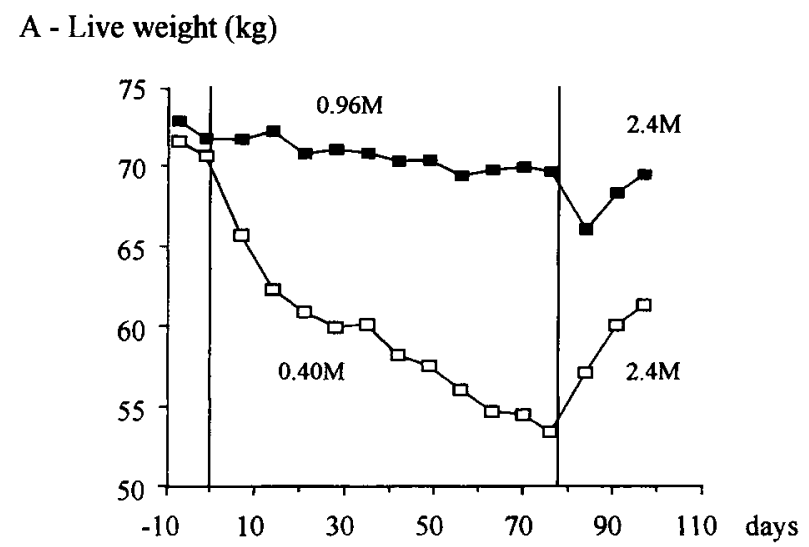

B - Non-esterified fatty acids ( $\mathrm{m} M$ )

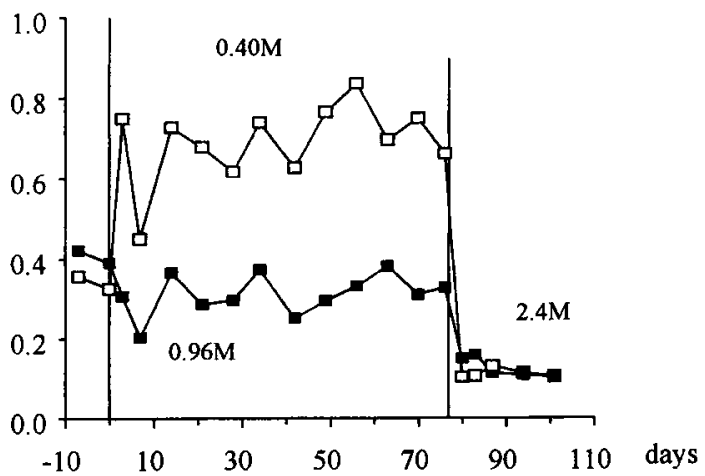

Figure 1. Temporal changes in live weight (A) and plasma non-esterified fatty acids (B) of dry ewes fed either at maintenance (M) or underfed and then refed (Bocquier, Caraty, Chemineau and Chilliard, unpublished). 
The weights of digestive tract and liver are positively related to present intake, rather than previous nutrition, and they change very rapidly (7-14 d; [16]). All components of the splanchnic area, in particular rumen, intestines and liver, appear to contribute more than proportionally to LW medium-term variations. Variation in rumen wall mass probably relates to rumen fill (bulk effect), whereas variations in intestine, and especially liver weight, are related to absorbed nutrients (see [79]). Weight variations involve only the epithelium of the intestines, but both epithelial and muscular layers of the rumen [64]. Rumen and probably intestine mass alterations are associated with changes in cell size and number, while liver weight changes are probably due totally to changes in cell size $([17,89]$; table $I)$.

During the first weeks of lactation, cows are in negative energy balance but, because at the same time their intake is increasing, the total weight and the protein mass of the gastrointestinal tract are elevated [54], while body lipid and protein reserves are mobilized. Thus, during this period, the metabolism of splanchnic tissues, under the predominant control of intake, is uncoupled from that of the other tissues, which depends mainly on nutritional and physiological status.

When nutrients are restricted, body tissues are generally mobilized (fat $>$ muscle $>$ bone) in the inverse order of their deposition, with the latest maturing tissues relatively more sensitive because of a lower physiological priority. Adipose tissue (AT) mobilization occurs broadly according to the following order: subcutaneous, perirenal, omental plus mesenteric, intermuscular, intramuscular and bone. This order is basically unaltered by physiological state, as shown by underfeeding dry or lactating cows [19]. On the other hand, in Barbary ewes which are frequently feed restricted, the supplementary fat depot of the tail $(3-4 \mathrm{~kg})$, which has a priority equivalent to internal fat [2], is continuously mobilized during long-term underfeeding. The absolute contribution of different AT differs, therefore, from their relative priority; with subcutaneous being the most labile but contributing less than the intermuscular AT which is, quantitatively, the main fat reserve.

Severely underfed dry ewes, initially differing in body lipid ( 10.3 versus $33.8 \mathrm{~kg}$ ) and protein (6.0 versus $8.6 \mathrm{~kg}$ ) content, mobilized (during 142-149 d) similar amounts of protein (1.6 versus $1.9 \mathrm{~kg}$ ), but different amounts of fat $(6.3$ versus $15.4 \mathrm{~kg}$ ) [81]. Ewes which were initially overfat ( $43 \%$ LW) stopped eating and died when still containing $16.1 \mathrm{~kg}$ lipids, while animals which were initially thinner ( $24 \%$ LW) died only when containing less than $1.8 \mathrm{~kg}$ lipids. The situation may be different during lactation, because fat ewes are able, without health problems, to mobilize as much as $13.5 \mathrm{~kg}(69 \%)$ of body lipids [36]. This difference between lactating versus dry ewes to cope with an intense body lipid mobilization is probably related to

Table I. Effects of a decrease in intake from $\mathrm{M}$ to $0.5 \mathrm{M}$ on mass, cell number and cell size of parts of the digestive tract (Nozière et al., unpublished data).

\begin{tabular}{lccc}
\hline & Small intestine & $\begin{array}{c}\text { Rumen } \\
\text { (mucosa) }\end{array}$ & $\begin{array}{c}\text { Rumen } \\
\text { (serosa + muscular layers) }\end{array}$ \\
\hline Mass & $-23 \%$ & $-37 \%$ & $-37 \%$ \\
Cell number & $-22 \%$ & $-43 \%$ & $-4 \%$ \\
Cell size & $+11 \%$ & $+3 \%$ & $-39 \%$ \\
\hline
\end{tabular}


the large drain of NEFA by the mammary gland (see below). That is also the case in early lactating dairy cows, whose body lipid mobilization varies between 20 and $80 \mathrm{~kg}$ (up to $60 \%$ ) over 8 weeks, according to milk potential, body condition and food supply [28].

The magnitude of body protein loss in underfed ruminants is not as well documented as lipid mobilization owing to difficulties with in vivo estimation. Data are mainly available in productive (growing or lactating) animals, but very few in adults at maintenance. Changes in body protein do not always follow changes in body fat. Well-fed high producing cows mobilize only a small amount of protein, whereas they lose a lot of body fat during the first 2 months of lactation. Underfed cows can, however, mobilize up to $13-15 \mathrm{~kg}$ (i.e. about $15 \%$ ) of their body protein, with muscle protein contributing (up to $8 \mathrm{~kg}$ ) approximately half of total body protein loss [26]. Furthermore, studies on fattening of old cows suggested that lactating cows may not regain all of the body protein mobilized and thus may not be able to avoid a decline in their muscle weight and muscle/bone ratio with ageing [87]. Use of protein reserves to support milk production during the negative protein balance period of lactation is fairly limited and when the dietary deficit attains $20-30 \%$ there is an adverse effect on milk yield [65]; presumably the physiological priority for protein is in favour of body structural and functional roles. During long-term underfeeding over two successive lactations the maintenance of body reserves takes priority over sustaining milk yield [94].

\section{DIGESTION}

A decrease in intake is known to result in an increase in diet digestibility, as a consequence of an improvement in the extent of ruminal digestion. This is mainly due to a longer retention time of feed particles in the rumen [53]. The microbial activity by itself is not modified, but the time of contact between microbes and feed particles is lengthened, together with a more efficient mastication, especially rumination, which leads to smaller particles, which are more easily accessible to microbes. This improvement of digestibility is more marked for diets rich in concentrates than for forage-based diets [76]. This general trend has been established from various experiments conducted with cattle and sheep fed at intake levels equal to or above $\mathbf{M}$ [30].

When ruminants are fed below M level, various responses are observed. The above described general trend can occur [66] but an absence of effect on digestibility has also been observed by Grimaud and Doreau [56] and even a decrease in digestibility has been observed by Grimaud et al. ([57] and unpublished data; table II), both trials comparing forage-

Table II. Effect of underfeeding on feeding behaviour and digestive processes in zebu cattle (Grimaud et al., unpublished data).

\begin{tabular}{lcc}
\hline Level of intake & High & Low \\
\hline Feed intake (kg DM/d) & 4.0 & 1.5 \\
Organic matter digestibility $(\%)$ & 68.5 & 54.7 \\
Turnover rate of particles in the rumen $\left(\mathrm{h}^{-1}\right)$ & 0.027 & 0.027 \\
Degradation rate of particles in the rumen $\left(\mathrm{h}^{-1}\right)$ & 0.025 & 0.018 \\
\hline
\end{tabular}


based diets given at $\mathrm{M}$ and $0.5 \mathrm{M}$ levels. As a decrease in intake under $M$ level generally results in a longer retention time, it can be supposed that a further increase in retention time does not allow improvement of the amount of organic matter degraded. Lowering intake below $\mathrm{M}$ level does not improve the efficiency of mastication, because the rate of intake in underfed animals is very high. In some particular cases such as fasting, a disturbance of rumination can be observed, due to an insufficient filling of the rumen. However these modifications are insufficient to explain why a reduction in digestibility sometimes occurs. The reason may be a limitation in microbial activity. This has not been clearly demonstrated by the in situ global methods (nylon bag technique) which are probably of insufficient sensitivity. A first explanation is the strong reduction in protozoa number [56], which could be due to a shortage in available energy. A limitation in energy or in specific nitrogenous or mineral nutrients could also reduce bacterial activity but experimental proofs are lacking.

The decrease in the amount of absorbable nutrients is accompanied by a drop in the absorption rate of volatile fatty acids (VFA) by the rumen wall [38]. This is due in part to the low concentrations in VFA in the rumen, but also to a $30 \%$ decrease in the absorptive capacity of the ruminal mucosa, of which the weight is reduced when animals are underfed. However, it can be thought that if VFA are not totally absorbed in the rumen, they are absorbed in the abomasum or in the large intestine.

It is concluded that the digestive processes in ruminants are not well adapted to a decrease in intake below $M$ level. With diets of low nutritive value, such a low intake is strongly detrimental for animals.

\section{TISSUE METABOLISM}

Both energy and protein metabolism are sensitive to nutritional conditions ( $f$ igure 2). Protein turnover is considerable even in the basal (fasting) state; this confers plasticity, allowing rapid response to challenges, and helps maintain homeothermy. Nutrient-driven changes in protein synthesis and protein degradation are determined mainly by protein supply, alteration of which effects significant responses in both absolute and fractional rates of whole body protein synthesis within 2 days. Subsequently, chronic (42 d) responses depend on body protein mass, because fractional rates of synthesis and degradation are stabilized [71]. Thus, in whole body terms, both net anabolism and catabolism appear to be determined primarily by changes in protein synthesis, with degradation less responsive.

\subsection{Splanchnic tissues}

The splanchnic organs are amongst the most active in the body of ruminants: they represent $6-9 \%$ of body weight and account for $40-50 \%$ of protein synthesis and oxygen consumption, divided almost equally between digestive tract and liver. The oxygen consumption, i.e. the energy expenditure, is positively correlated to metabolizable energy intake [70], mainly by means of variations in blood flow, which depends on intake [79]. Blood flow responds very rapidly and strongly (-50\% within $2 \mathrm{~d}$ ) to fasting [74], owing both to nervous mechanisms and nutrient effect. At mid-term, a decrease in intake from $M$ to $0.5 \mathrm{M}$ led to decreases in the portal and hepatic blood flows by 22 and $19 \%$ and in oxygen consumption by 34 and $39 \%$, respectively [80]. This was accompanied by a lower oxygen extraction rate. These variations occurred within 1 week and were then stabilized. On the contrary, after a 80 -d undernutrition period, a 30-d 

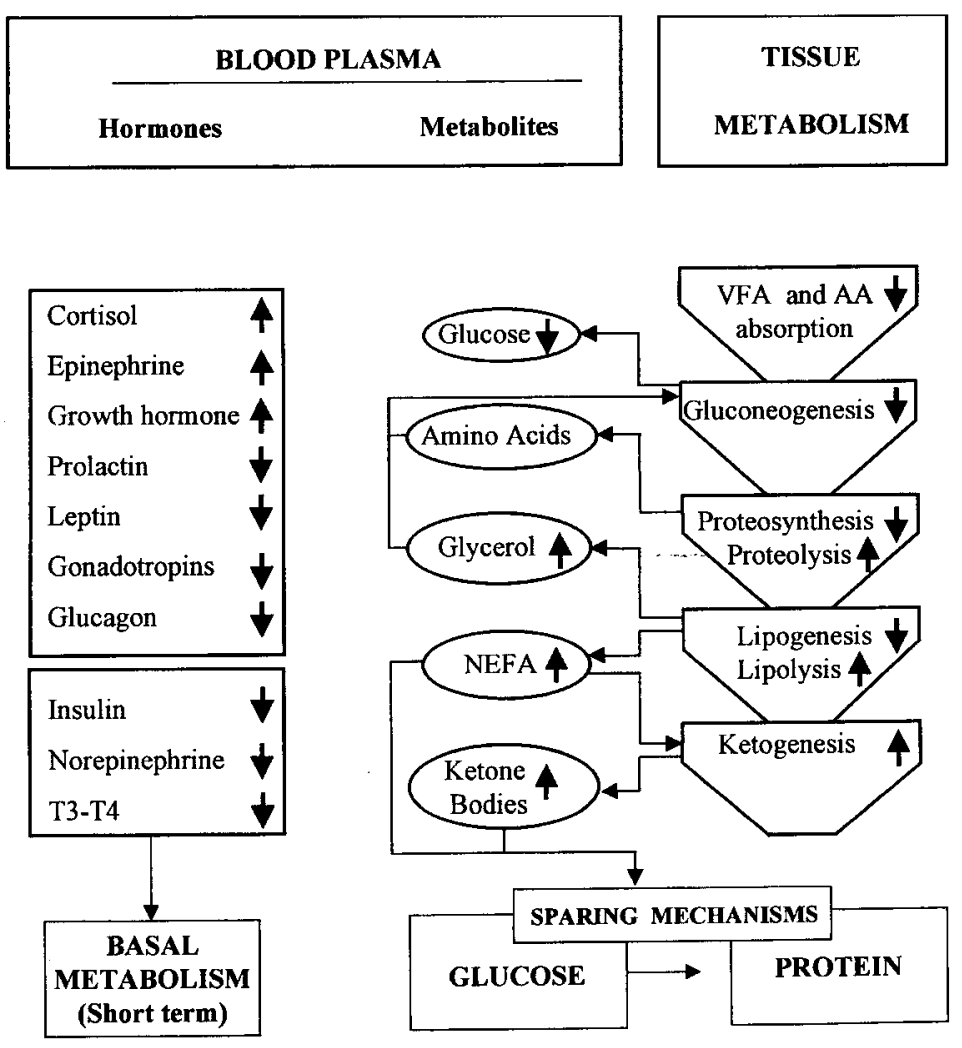

Figure 2. Metabolic and endocrine adaptations to undernutrition in the ruminant (AA, amino acids; NEFA, non-esterified fatty acids; VFA, volatile fatty acids; T3-T4, thyroid hormones).

refeeding was necessary to restore oxygen consumption at the level observed before restriction [50]. On the other hand, portal and hepatic blood flows were better related to milk yield than to metabolizable energy intake in early lactating cows [43], probably because the intensity of splanchnic metabolism is determined by the nutrient fluxes arising from the combination of body reserve mobilization and digestive tract metabolism.

A lower intake results in a slight decrease in the fractional protein synthesis rate in the digestive tract, which could explain in part weight changes, whereas fractional synthesis rate does not vary in the liver [73]. Variations in degradation rate are certainly involved in the modification of splanchnic tissue mass, but direct measurements are scarce in ruminants. An increase in mRNA of cathepsin D, which is involved in a proteolytic pathway, in the muscular layers of the rumen (Nozière et al., unpublished data) confirms this hypothesis.

\subsection{Muscle and skin}

The contribution of muscle to energy expenditures appears to be less sensitive to nutritional and physiological state than 
that of splanchnic tissues [80]. In contrast to muscle, skin oxygen consumption varies three-fold between 0.6 and $1.4 \mathrm{M}$, while at the lower intake there is a substantial anaerobic energy contribution to support synthesis of skin waxes [60]. Muscle protein synthesis is more responsive than degradation to undernutrition and this allows muscle to continually provide AA for maintenance of vital processes in other tissues [11]. Skin has a greater fractional rate of synthesis $(\times 2-3)$ than muscle but makes a similar contribution to whole body protein synthesis (15-20\%; [72]), with the fractional rate of synthesis proportional to intake. The proportion of skin protein synthesis linked to wool production appears to vary between ovine breeds but is not altered between high and low nutritional states [60].

The mobilization of muscle protein in the early lactating goat results from decreased synthesis and increased degradation. This could be due in part to the decrease in insulinaemia at this physiological stage, since this hormone inhibits the ubiquitin-proteasome proteolytic pathway by decreasing the ubiquitin gene expression [68]. The sensitivity of muscle proteolysis to insulin inhibition is however higher during early lactation [92], and this probably provides a mechanism to avoid excessive protein mobilization during lactation.

\subsection{Adipose tissue}

Ruminant body lipids can be either synthesized de novo, mainly in AT from acetate, and to a lower extent from lactate, or arise from hydrolysis of plasma triglycerides (TG) by lipoprotein lipase (LPL). The decrease in the rates of FA synthesis and LPL activity during fasting, and restoration during refeeding, are slower in ruminants than in non-ruminants, owing to a buffering effect by the rumen.
Four to eight days are required to achieve minimum rates, and more than $10 \mathrm{~d}$ to restore pre-fasting rates $[37,63]$, and these changes are due in part to pretraductional regulations of key enzymes [12, 14]. In the long term, AT anabolic activities are positively related to daily energy balance. This relationship is exponential, with anabolic activities being negligible when the animals are in negative energy balance [27].

The regulation of amount and activity of key lipogenic enzymes with undernutrition seems to be due primarily to a decrease in insulin secretion (table III). The short-term regulation of enzyme activities is probably exacerbated by changes in plasma concentrations of lipogenic substrates, including acetate (positive effect) and non-esterified FA (NEFA) (negative effect). The increase in growth hormone (GH) secretion that is generally associated with undernutrition is also of importance because this hormone markedly decreases AT response to the lipogenic effect of insulin [4]. It was demonstrated recently in the rat that injection of neuropeptide $\mathrm{Y}$ into the hypothalamic paraventricular nucleus increased independently food intake and expression of the LPL gene in AT [5]. Thus, complex relationships may exist between the regulations of food intake, nutrient utilization and lipid storage.

NEFA release from $A T$ is the net result of lipolysis of adipocyte TG by hormone sensitive lipase, and re-esterification in situ of some of the liberated FA. Plasma NEFA concentration increases during fasting until a plateau (about $1 \mathrm{mmol} / \mathrm{L}$ ) is reached after 4-8 d. Return to prefasting concentrations after refeeding is usually very rapid (1-2 d) (figure 1).

The increased NEFA mobilization during the period of negative energy balance in early lactation [22], and during chronic undernutrition [41], is due to a decrease in FA re-esterification, together with 
increased lipolysis [42]. Lipolysis is maintained as lactation progresses but re-esterification increases (in agreement with data in vitro; [52]), providing an important substrate cycle which is energetically expensive but offering metabolic flexibility to maintain the potential for rapid changes in flow of FA substrates to other tissues.
These responses can be linked to changes in glycaemia and insulinaemia, and increased epinephrine (EPI) secretion. Indeed, glucose and insulin stimulate FA re-esterification, whereas insulin inhibits and EPI generally stimulates lipolysis. Preliminary results suggest that lipolysis is subject to seasonal variations, since short

Table III. Effects of feeding level and photoperiod on adipose tissue metabolic activity and plasma hormones and metabolites (five ewes per group). Adapted from Bonnet et al. [12, 13] and Chilliard et al. [31, 32].

\begin{tabular}{|c|c|c|c|c|c|}
\hline \multirow{2}{*}{$\begin{array}{l}\text { Feeding level } \\
\text { Photoperiod }^{2}\end{array}$} & \multicolumn{2}{|c|}{25} & \multicolumn{2}{|c|}{200} & \multirow[b]{2}{*}{ Effects } \\
\hline & $S$ & $\mathbf{L}$ & $S$ & $\mathrm{~L}$ & \\
\hline Dry matter intake $(\mathrm{g} / \mathrm{d})^{3}$ & $290^{\mathrm{a}}$ & $302^{\mathrm{a}}$ & $1588^{b}$ & $1589^{\mathrm{b}}$ & $\mathbf{F}$ \\
\hline Body weight $(\mathrm{kg})$ & 71.1 & 71.6 & 76.1 & 74.9 & 一 \\
\hline \multicolumn{6}{|l|}{ Perirenal adipose tissue } \\
\hline Weight $(\mathrm{kg})$ & 2.31 & 2.14 & 2.40 & 2.26 & - \\
\hline Adipocyte volume (pl) & 935 & 843 & 712 & 867 & - \\
\hline Fatty acid synthase ${ }^{4}$ & $49^{a}$ & $44^{\mathrm{a}}$ & $206^{\mathrm{b}}$ & $241^{\mathrm{b}}$ & $\mathrm{F}$ \\
\hline $\mathrm{G} \mathrm{PDH} \mathrm{PH}^{4,5}$ & $149^{\mathrm{a}}$ & $147^{\mathrm{a}}$ & $548^{b}$ & $576^{\mathrm{b}}$ & $\mathbf{F}$ \\
\hline Malic enzyme $^{4}$ & $74^{\mathrm{a}}$ & $87^{\mathrm{a}}$ & $147^{b}$ & $208^{\mathrm{c}}$ & $F, P, f \times p$ \\
\hline $\mathrm{G}^{3} \mathrm{PDH}^{4,6}$ & $4169^{a}$ & $3217^{a}$ & $6625^{\mathrm{b}}$ & $8059^{b}$ & $\mathrm{~F}$ \\
\hline Lipoprotein lipase ${ }^{4}$ & $136^{\mathrm{a}}$ & $157^{\mathrm{a}}$ & $496^{b}$ & $525^{\mathrm{b}}$ & $\mathrm{F}$ \\
\hline Leptin mRNA $^{7}$ & 0.89 & 1.86 & 1.64 & 2.33 & $f, P$ \\
\hline \multicolumn{6}{|l|}{ Plasma metabolites $(\mu \mathrm{M})$} \\
\hline NEFA & $694^{\mathrm{a}}$ & $493^{\mathrm{b}}$ & $51^{\mathrm{c}}$ & $41^{\mathrm{c}}$ & $\mathrm{F}, \mathrm{p}$ \\
\hline 3-OH-butyrate & 435 & 474 & 549 & 598 & - \\
\hline Glucose & $3243^{a}$ & $3181^{a}$ & $3880^{b}$ & $3508^{a b}$ & $\mathrm{~F}$ \\
\hline Acetate & $116^{\mathrm{a}}$ & $203^{a}$ & $645^{b}$ & $727^{\mathrm{b}}$ & $\mathrm{F}$ \\
\hline Triglycerides & $83^{\mathrm{ab}}$ & $49^{\mathrm{a}}$ & $122^{b}$ & $113^{\mathrm{b}}$ & $\mathrm{F}$ \\
\hline Urea & $2567^{a}$ & $2668^{a}$ & $8175^{b}$ & $8194^{b}$ & $\mathrm{~F}$ \\
\hline \multicolumn{6}{|l|}{ Plasma hormones } \\
\hline Prolactin (ng/mL) & $7.0^{\mathrm{a}}$ & $19.3^{b}$ & $13.2^{\mathrm{ab}}$ & $34.4^{c}$ & $F, P, f \times p$ \\
\hline Somatotropin (ng/mL) & 0.55 & 0.96 & 0.92 & 0.65 & - \\
\hline Insulin $(\mu \mathrm{U} / \mathrm{mL})$ & $14.6^{\mathrm{a}}$ & $16.0^{\mathrm{a}}$ & $38.9^{\mathrm{b}}$ & $44.9^{\mathrm{b}}$ & $\dot{F}$ \\
\hline Leptin $(\mathrm{ng} / \mathrm{mL})^{8}$ & $2.5^{\mathrm{a}}$ & $3.2^{\mathrm{a}}$ & $3.4^{\mathrm{a}}$ & $4.1^{\mathrm{b}}$ & $\mathrm{F}, \mathrm{P}$ \\
\hline
\end{tabular}

'Percent of maintenance; ${ }^{2} \mathrm{~S}=8 \mathrm{~h} / \mathrm{d}$ light $\mathrm{L}=16 \mathrm{~h} / \mathrm{d}$ light; ${ }^{3}$ recorded during the 2 days before slaughtering; ${ }^{4}$ unit $=\mathrm{nmol} / \mathrm{min} / 10^{6}$ adipocytes; ${ }^{5}$ glucose-6-phosphate dehydrogenase; ${ }^{6}$ glycerol-3-phosphate dehydrogenase; ${ }^{7}$ arbitrary units; ${ }^{8}$ adjusted means using pre-experimental value as covariate.

a, b, c Figures with different letters differ significantly $(P<0.05)$; F, P or $\mathrm{f}, \mathrm{p}$ : significant effect of feeding level or photoperiod, respectively $(P<0.05$ or 0.10$)$; $\mathrm{f} \times \mathrm{p}$ : significant interaction $(P<0.10)$. 
days increase plasma NEFA in the underfed ewe (table III). This could reflect an increased potential for AT mobilization during winter food shortage.

The lipolytic response in vivo to a $\beta$ adrenergic challenge in dry non-pregnant cows is sharply decreased post-feeding, and increased by mid-term underfeeding [29], but not by $\mathrm{GH}$ administration [47]. The AT response to EPI challenge in underfed ewes can be reproduced using a $\beta$-adrenergic compound. It is partly due to $\beta_{2^{-}}$, but not to $\beta_{1^{-}}$or $\beta_{3^{-}}$-adrenergic stimulation, while the antilipolytic $\alpha_{2}$-response seems to be of little importance ([46]; table IV). Effects of fasting or underfeeding on in vitro basal and/or catecholaminestimulated lipolysis are inconsistent [30], but fasting seems to decrease the number of antilipolytic adenosine receptors, to increase the affinity of $\beta$-adrenergic receptors [62], and to increase hormone sensitive lipase mRNA in cattle AT [14]. Response to a $\beta$-adrenergic challenge in well-fed lactating ewes is mainly related to the amount of body lipids, but to energy balance when animals are underfed (figure 3). This suggests that AT lipolytic potential is regulated according to physiological needs rather than by the amount of lipid stores, with the probable exception of very lean animals [24].
During prolonged underfeeding, plasma NEFA level tended to reach a plateau or to decrease after some weeks [30], perhaps as part of a general mechanism to spare body lipids and so prolong survival [93], and/or to alleviate toxic effects of high ( $2 \mathrm{mmol} / \mathrm{L}$ ) NEFA concentrations [83]. These hypotheses are also in keeping with calculations showing that body fat loss in vivo, or NEFA entry rate, in fasting animals is generally much lower than lipolytic capacity in vitro. This can be due to numerous antilipolytic feedback mechanisms, mediated in part by NEFA and ketone body concentrations, to increased re-esterification of excess FA during starvation [20] and to a decreased lipolytic response to catecholamine on prolonged fasting, possibly linked to decreases in adipocyte size or the development of hypothyroidism [93]. The situation is somewhat different in lactating animals because the high rate of NEFA use by the mammary gland allows a greater expression of the AT lipolytic potential without major increases in plasma NEFA concentrations [29].

\subsection{Interorgan relationships}

The basal glucose requirements of ruminants are similar to those of non-ruminants and are determined by the amount

Table IV. Glycerol response area (mM.min) during adipose tissue perfusion (120 min) by in situ microdialysis of either $\beta$-adrenergic $(\beta$-A) compounds or epinephrine in underfed ewes (adapted from Ferlay et al. [48]).

\begin{tabular}{lccc}
\hline & \multicolumn{3}{c}{ Concentration } \\
\cline { 2 - 4 } Adrenergic compounds & $10^{-6} \mathrm{M}$ & $10^{-5} \mathrm{M}$ & $10^{-4} \mathrm{M}$ \\
\hline Isoproterenol (non-selective $\beta-\mathrm{A})$ & 1.3 & 10.1 & 9.4 \\
Terbutaline (selective $\beta 2-\mathrm{A})$ & 2.5 & 4.9 & 3.6 \\
CL316243 (selective $\beta 3$-A) & 1.2 & 1.0 & 0.7 \\
Epinephrine ( $\alpha 2$ - and $\beta$-A) & 1.2 & 7.7 & 9.7 \\
\hline
\end{tabular}




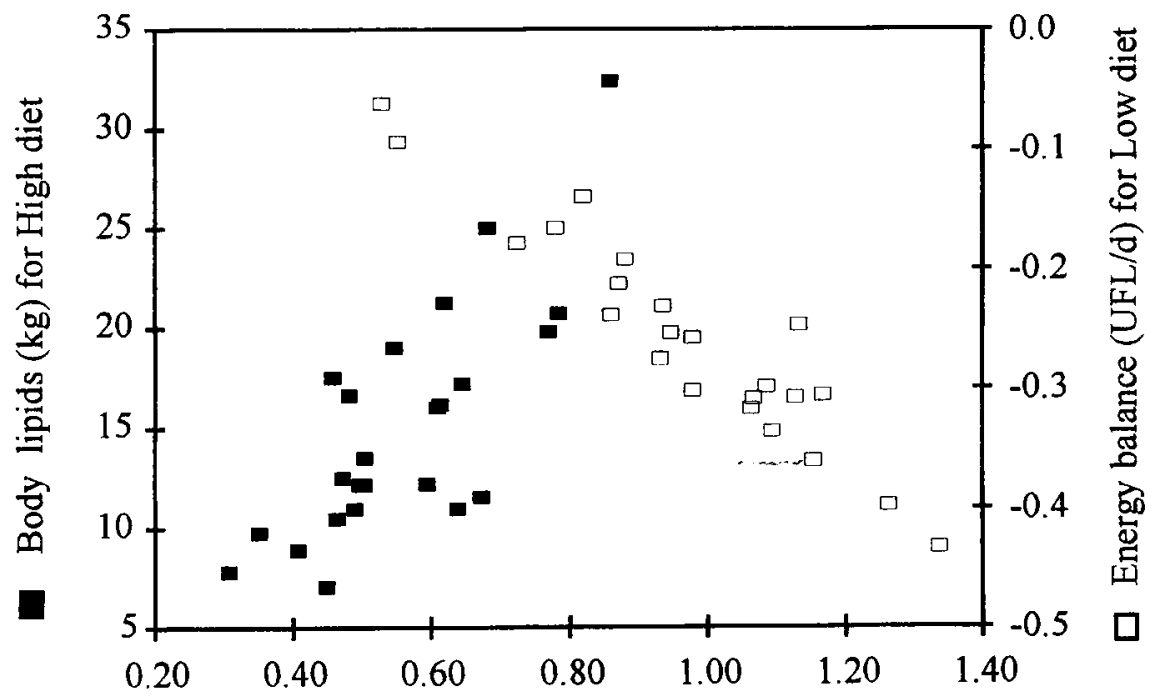

Plasma NEFA $(\mathrm{m} M)$

\section{High diet $\square$ Low diet}

Figure 3. Plasma non-esterified fatty acid (NEFA) concentrations (predicted values) after a $\beta$-adrenergic challenge mostly depend on the amount of body lipids in well-fed lactating ewes (High diet), but on energy balance in underfed ewes (Low diet) (adapted from Bocquier et al. [10]).

which is irreversibly catabolized $\left(\mathrm{CO}_{2}\right.$ and acetyl units), usually approximating to $30 \%$ of glucose flux in dry non-pregnant animals. These oxidative pathways support vital processes, such as brain and muscle metabolism and NADPH production, while the remainder of the flux represents glucose transformations into glucogenic metabolites.

Gluconeogenesis decreases during undernutrition owing to the decrease in the entry of its main precursor, propionate (figure 2). This decrease is partly compensated by gluconeogenesis from glycerol provided by AT lipolysis (20\% of glucose carbon), from amino acids (AA) from proteolysis $(50 \%$, alanine and mainly glutamine), and by lactate recycling. In underfed animals, AA provide essential glucose carbon and, for the fasted state, supply of exogenous glucose or propionate, equivalent to the basal rate of glucose oxidation, reduces nitrogen $(\mathrm{N})$ loss by $50 \%$ [67]. This effect is not seen with other energy-substrates (e.g. acetate) and indicates that $50 \%$ of basal AA catabolism may be linked to other metabolic demands.

During fasting, the NEFA released by AT can account, in theory, for total energy requirements and thus spare glucose and AA as oxidative fuels [83]. The muscle use of NEFA is increased six-fold and is 
sufficient to account, with associated ketone body oxidation, for $80 \%$ of the tissue oxygen exchange. When ruminants are in positive energy balance, ketone bodies arise mainly from metabolism of butyrate by the rumen wall, and secondarily from hepatic partial oxidation of NEFA and TG. During undernutrition whole body ketogenesis increases up to seven-fold with the main site of synthesis switched to the liver. The ability of periplieral tissues to utilize NEFA and ketones bodies, and of liver to synthesize TG and to secrete lipoproteins, avoids attainment of toxic concentrations of plasma NEFA and determines whether clinical ketosis will be established. Fasted muscle, for example, sharply decreases glucose oxidation, with NEFA and ketone body catabolism accounting in approximately equal parts for energy expenditure [82].

Liver steatosis increases in fasted dry cows owing to increased uptake of NEFA and simultaneous decreased hepatic output of TG [85]. The low ability of ruminant liver to secrete very low-density lipoproteins (VLDL) relates to its low capability for hepatic FA synthesis de novo [25]. This can be related to the decrease during underfeeding in ewe cardiac muscle LPL activity [12], because this tissue is probably using mainly ketone bodies, contrary to the rat cardiac muscle that is using mainly circulating TG secreted by the liver during underfeeding. In cows that are fat at calving and then underfed during early lactation, liver steatosis is particularly high owing to marked AT mobilization [84] and because apolipoprotein B synthesis and VLDL secretion potentials are extremely low. Hepatic apolipoprotein B concentration increases, however, after 2 or 3 months of lactation, but without any change in mRNA abundance [58].

\section{ENDOCRINE REGULATIONS}

Endocrine and metabolic responses to undernutrition (figure 2) are aimed primarily at maintaining, within certain limits, the constancy of the internal environment (homeostasis). Short-, medium- and long-term adaptations in underfed animals are essential for the orderly mobilization of endogenous substrates (body reserves) required for homeostasis and, probably, also for sparing glucose, lowering metabolic rate and energy expenditure. Whereas homeostatic regulations are directed towards the survival of individuals, teleophoretic regulations ensure the perpetuation of the species, through integrated reproductive functions (breeding, pregnancy, lactation and growth). Teleophoretic hormones (produced mainly by the pituitary gland and reproductive organs) co-ordinate changes in whole body metabolism to establish the priority of these physiological requirements. There can be, however, some situations (especially in underfed animals) where the demands of teleophoresis lead to disruptions in homeostasis (e.g. ketosis, fatty liver, impaired reproduction) [25].

Insulin is hypoglycaemic and plays a central role in homeostatic control with its plasma concentration positively correlated with energy intake (table $I I I$ ) and propionate absorption. Low insulin concentrations decrease the use of glucose and other nutrients, by muscle and AT, for oxidation and storage as protein and fat, and increase hepatic ketogenesis [95], decrease propionate use and promote the use of endogenous substrates for gluconeogenesis [15].

Glucagon probably has a main role in induction of hyperglycaemia during stress, rather than involvement in minute-tominute regulation of glycaemia, through increased hepatic AA utilization for gluconeogenesis [15]. Glucagon secretion 
and plasma insulin/glucagon ratio are generally decreased by undernutrition [75].

Thyroxine and/or triiodothyronine secretion and plasma concentrations are decreased by undernutrition in ruminants [30]. This could result in decreased tissue oxidation and basal metabolism, with reduced rates of protein and fat turnover, thus sparing energy and limiting the rate of body fat and protein mobilization.

Norepinephrine plasma concentration tends to decrease during undernutrition probably due to reduced sympathetic activity [51]. However, EPI and cortisol secretions are enhanced during hypoglycaemia, while the metabolic clearance rate of EPI decreases on fasting [51]. This favours glycogenolysis, gluconeogenesis, proteolysis and lipolysis, with these effects further reinforced by the hypoinsulinaemic effect of EPI [15, 47].

Plasma GH concentrations are high in underfed growing [6] and lactating [8] ruminants. This increase probably relates, in part, to the decreased clearance rate of $\mathrm{GH}$ and the low level of insulin-like growth factor I (IGF-I) during undernutrition, thus reducing the negative feedback on GH secretion [55]. Responses of plasma GH to undernutrition are however less clear in dry non-pregnant adult cows [47] and ewes (table III) than in growing or lactating animals, where its main role is teleophoretic. It is not clear if increased plasma GH during undernutrition plays a role in short-term homeostasis because several days lapse before insulin-resistance is induced in ruminants[15]. In the medium-term, insulin-resistance spares glucose and decreases gluconeogenesis from AA and, hence, favours net protein synthesis with decreased protein mobilization and urea nitrogen loss.

Plasma IGF-I concentrations decrease (whereas GH values increase) in underfed growing or lactating animals, with a reduced response in IGF-I to $\mathrm{GH}$ administration [33]. Thus, the depressed IGF-I secretion which occurs because of the resistance developed by the liver, or other tissues, to $\mathrm{GH}$ action, may provide a homeostatic regulation that curtails the teleophoretic stimulation of nutrient use in situations where absolute or relative nutrient availability is limited.

The metabolic role of prolactin remains unclear. Plasma prolactin is sharply decreased, however, by short days, as well as by short- and medium-term decreases in food intake in dry cattle, and lactating [8] or dry (table III) sheep. One hypothesis is that additive responses of prolactin to daylength and food intake are regulatory factors in the seasonal changes of body reserves.

Leptin, a hormone produced by adipose tissue and positively linked to adiposity, may serve as a signal of body fat level ('adipostat') to the central nervous system (CNS), because leptin receptors have been identified in the choroid plexus and in the hypothalamus, where one of its roles is to depress neuropeptide $Y$ and then to limit food intake. In rodents, it has been demonstrated that leptin also regulates energy expenditure and reproduction [3]. Its roles in ruminants remain to be determined but AT leptin gene expression is decreased by underfeeding (table III) and increased by neuropeptide $Y$ [44] in sheep as in rodents.

\section{ENERGY AND NITROGEN EXPENDITURES}

Energy expenditure of a given animal largely depends (up to $50 \%,[78]$ ) on its feeding level and, as a consequence, on its nutritional status. A large part of the decrease in the course of underfeeding can be explained by the LW loss of animals and the range of expenditures is narrowed when expressed per $\mathrm{kg} \mathrm{LW} \mathrm{W}^{0.75}$. These 
decreases per $\mathrm{kg} \mathrm{LW}^{0.75}$ comprised between 12 and $23 \%$ [30].

The variation in energy expenditure when animals are underfed occurs in a triphasic way. First, a short-term (1-2 d) strong decrease which results from the reduction in the amount of food ingested and of nutrient absorbed. Most muscular activities related to intake (chewing, locomotion and posture) decrease with underfeeding. Muscular activity for chewing is proportional to feed intake, whereas activity of the digestive tract may not vary with intake. It is likely that expenditures related to digestive secretions, active transport of absorbed nutrients or substrate cycles are related to the level of intake. A transient decrease in energy expenditure per unit of tissue mass probably occurs, because blood flow and $\mathrm{O}_{2}$ consumption are reduced very rapidly (1-2 d) by fasting [74], before a significant decrease in splanchnic tissue weight is achieved. This transient decease could be related to reductions in insulinaemia, thyroid hormone and sympathetic activity.

The second step of decline in expenditure corresponds to the phase of decrease in the mass of splanchnic tissues, within 1-3 weeks after the beginning of undernutrition. A compilation of several midterm experiments (several weeks) shows that the contribution of different tissues to variations in energy expenditure is 17-61\% for portal-drained viscera, $14-44 \%$ for liver and 5-7\% for skeletal muscles [79]. These data stress the importance of splanchnic tissues in the variations of energy expenditure of ruminants when the level of intake varies, since their relative contribution to these variations is higher than their absolute contribution: $16-29 \%$ for portal-drained viscera and $17-31 \%$ for liver. Variation in oxygen consumption with intake corresponds to a variation in tissue weight of the same extent [16]. It can be deduced that the oxygen consumption per gram tissue is not altered by undernutrition, at least at this time scale.

The third step is the decrease, at a slower rate, that occurs when the weight of splanchnic tissues is stabilized, whereas muscles and adipose tissues are mobilized on a longer period. As the daily oxygen consumption per gram of tissue is higher for digestive tract $(1.7 \mathrm{mmol})$ and liver $(4.9 \mathrm{mmol})$ than for hindquarter, mainly composed of muscle (0.3 mmol; [80]), the decrease in energy expenditure is more rapid during the first weeks of underfeeding than later owing to the modification of the composition of body weight loss. At long term, energy expenditure per $\mathrm{kg}$ $\mathrm{LW}^{0.75}$ may vary according to changes that occur in the relative proportion of the different tissues (splanchnic/muscles/AT). After a prolonged undernutrition, the decrease in muscle and AT masses, when the mass of splanchnic tissues is stabilized, could lead to an increase in energy expenditure expressed per $\mathrm{kg} \mathrm{LW}^{0.75}$ [78] since the oxygen consumption of muscle is low and that of AT is very low. This may sometimes not be apparent because other factors may act in the opposite way in thin animals where a trend towards hypoinsulinaemia decreases the expenditures of lean tissues, and because the physical activity is reduced. Furthermore, when food supply was imposed at different levels, long-term adjustment of energy expenditure was achieved through variation in body composition and different equilibrium $L W$ were obtained for each level of intake [91].

Metabolic losses of $\mathrm{N}$ in cattle include endogenous faecal losses, which represent 75-90\% of the total, urine losses and, to a lesser extent, dermal losses. Faecal losses are correlated to indigestible dry matter (DM) and thus to DM intake [88] owing to the abrasive effect of digesta on cell desquamation, and to an increase in digestive secretions with intake. When protein intake decreases, the concentration of 
waste $\mathrm{N}$, as urea, decreases in blood and the fractional uptake of $\mathrm{N}$ compounds by the kidney decreases [34] so that urinary $\mathrm{N}$ losses are reduced. After the initial rapid decrease in $\mathrm{N}$ losses when animals are underfed, a progressive decrease in these losses occurred during a 5-month underfeeding [56]. Wool growth is reduced by undernutrition and can even stop in extreme cases [81]. This is probably more related to limiting amino acids than to energy shortage. Reduced urinary $\mathrm{N}$ loss could result in enhancing $N$ recycling in the rumen, especially in camels [40] and thus improve the availability of fermentable $\mathrm{N}$ for rumen micro-organisms.

The above considerations show that the adaptation to undernutrition involves an obligatory catabolism of part of the body proteins and other structural components, and that there is no true decrease in the energy expenditure per gram of each individual tissue, except transiently at the beginning of undernutrition when exogenous nutrient fluxes decrease. It is, of course, important not to assume that the strategies for coping with undernutrition adopted by animals are the same between species, breeds or individuals. As a consequence their plasticity and their respective abilities to decrease energy expenditure and to mobilize body reserves without irreversible after-effects may greatly differ. Among herbivores, camels are particularly well adapted to spare energy, protein and water. They seem to be able to endure a prolonged fasting although mobilizing a relatively small amount of body lipids [23]. This is probably related in part to the numerous physiological adaptations of these animals, including a very low fasting heat production (when compared to sheep or cattle) and several physiological and endocrine mechanisms for decreasing water losses and body temperature. Within the ovine species, and beside large differences in the anatomical distribution of fat reserves between fat-tailed Barbary [2] and thin-tailed Lacaune ewes, the relative LW loss of fat-tailed ewes [69] was far lower than that observed in Lacaune ewes [7], when fed at the same energy level $(0.3-0.5 \mathrm{M})$. This suggests that Barbary sheep may have developed specific mechanisms to decrease energy expenditures.

\section{CONSEQUENCES ON REPRODUCTION}

Effects of undernutrition on reproductive processes occur at the different steps of the animal's life: puberty is delayed [45], ovulation is suppressed [59] or postpartum ovulation occurs later in adult female $[9,18]$ and embryo mortality is increased [59]. In fact, undernutrition alters all regulatory levels of the reproductive function (hypothalamus-pituitary-gonad) through mechanisms that may differ according to physiological stage and species. Because major effects of undernutrition seem to occur on the CNS, we emphasized the description of these mechanisms.

In the female, follicular maturation and ovulation rely on the action of gonadotropins, and specially luteinizing hormone (LH), which is produced and released from the pituitary gland. Furthermore, LH release depends on gonadotropin releasing hormone (GnRH) stimulation. Reduction of $\mathrm{LH}$ pulse frequency by undernutrition is particularly evident before puberty [45] and more variable in adult ruminants [86]. These effects are due to a reduction in GnRH release, while pituitary sensitivity to GnRH is not altered. It has been shown that depression of LH pulsatility by underfeeding is limited in ovariectomized ewes, compared to oestradiol-treated ewes or intact ewes. Therefore, the effect of undernutrition on the reduction of LH pulsality may be due to the reinforcement of the negative feedback of oestrogens on the GnRH release. 
Nutrition seems to exert its effects on reproduction by two types of mechanisms: a so called 'dynamic effect' which is due to short-term changes in the energy balance and associated effects on circulating blood metabolites and hormones. The second mechanism, which is called 'static effect', is due to the long-term effect of nutrition and can be related to the level of body reserves. For instance, the duration of post-partum anovulatory period mainly depends on the nadir of energy deficit in the dairy cow [18], while in the beef cow this period mainly depends on the level of fat reserves [1]. In the dairy ewe, the duration of the anovulatory period equally depends on these two mechanisms [9]. The dry ewe also responds to a transient (a few weeks) overfeeding by an increment of the ovulation rate when in poor body condition, while this overfeeding is without effect in the ewe in good condition [59].

Changes in circulating metabolites and hormones during the adaptation to undernutrition (figure 2) may serve as signals on the animal's nutritional status. It seems that glycaemia and insulinaemia are particularly efficient at the CNS level, while IGF-I is more potent at the ovary level. Systemic glucose infusion to underfed ewes restored LH pulsability, while an induced hyperinsulinaemia, which depresses glucose availability, reduced LH pulsatility [35]. Therefore, availability of energy substrates (glucose, etc.) at the CNS level may be the main cue, and hormones (insulin, IGF-I) that control substrate entry may only have an accompaniment role.

At a given level of energy deficit, animal adiposity (static component) may modify the effects of undernutrition on reproduction. In some ruminants, which are seasonal breeders such as sheep, photoperiod is the main factor that allows (short days) or prevents (long days) establishment of the breeding period. During the natural breeding period, a severe undernutrition ( $40 \%$ of energy requirements) does not alter LH pulsatility in fat ewes, but lean ewes $(<15-20 \%$ fat in the body) have a depressed LH pulsatility (Bocquier et al., unpublished results). This interaction between season, nutrition and adiposity in ewe is probably modulated through leptin gene expression in adipose tissue [13] and plasma level [32], which both depend on photoperiod as well as on feeding level at a given level of fatness (table III). We hypothesize that a lower basal plasma leptin concentration during the breeding season (short days) may enhance the sensitivity to its probable regulatory effect on reproduction, with undernutrition further depressing plasma leptin concentration below a threshold sufficient to block the reproductive processes.

\section{GENERAL CONSIDERATIONS AND CONCLUSIONS}

Adaptation of ruminants to undernutrition results from numerous digestive, metabolic and endocrine changes, whose relative importances depend largely on the severity and the duration of the feed restriction.

The first change after the start of undernutrition is the decrease, within $24 \mathrm{~h}$, in energy expenditures linked to intake and to nutrient handling by splanchnic tissues. This is rapidly followed, within 1 week, by a decrease in the mass of these metabolically active tissues, which can account for $40-70 \%$ of the short-term decrease in whole body energy expenditure. Simultaneously, body fat and protein mobilization starts. The intensity of protein mobilization from muscle, which results from a substantial decrease in protein synthesis is however limited because the gluconeogenic requirement for $\mathrm{AA}$ is reduced by glucose sparing mechanisms, and by the increased use of NEFA and ketone 
bodies, instead of acetate and glucose, for energy metabolism. These changes in nutrient selection are co-ordinated by low insulin and IGF-I, and high cortisol, GH and EPI concentrations. Decrease in tissue oxidative activity is probably due to decreased sympathetic activity and lowered insulinaemia and thyroidaemia. The decrease in thyroid hormone concentration could also limit excessive mobilization of body fat and protein. Furthermore, body fat mobilization is a self-limited process, which ultimately cannot overflow without metabolic disorders resulting from the limited ability of tissues to use NEFA and ketone bodies as energy sources.

A decrease in diet digestibility, which seems to be a counter-adaptation, frequently occurs during undernutrition. Decreased nitrogen excretion by the kidney and recycling of urea to the rumen could spare body protein and provide an efficient mechanism to improve the digestion of poor quality forages with a low nitrogen content.

Although experimental data are very limited, in the long-term a significant and true adaptation to underfeeding does not seem to exist because there is no evidence that energy expenditure per unit of tissue mass decreases. Hence, the reduction in whole body energy expenditure is probably due mainly to decreases in the mass of splanchnic, muscular and adipose tissues. This is in keeping with data and concepts arising from observations on chronic energy deficiency in humans [49, 90], although this is still controversial [39].

Animal survival duration depends then on the level of body reserves before undernutrition, and on the kinetics and physiological limits of fat and protein mobilization. Again, few data are available in ruminants, but extensive studies in the human, rat and birds [21] have shown that, in lean animals, the duration of fasting is limited by lipid exhaustion and, hence, by energy availability for gluconeogenesis.
The final step corresponds to a rapid mobilization of body proteins, leading to death before $50 \%$ depletion has occurred, and an increase in survival behaviour based on food foraging. The situation is somewhat different in fat, or obese, animals because body lipid mobilization allows efficient protein sparing, hence sharply increasing the duration of survival. Slow loss of body protein may continue, however, until a lethal stage of cumulative depletion is reached, long before body fat reserves are exhausted. There is only one trial where body composition was monitored in long-term underfed adult ruminants [81] and the data suggest that other mechanisms may occur, because fat ewes died before less than 25-30\% of their body protein and $50 \%$ of their body lipids were mobilized. The animals did, however, stop eating, probably because of metabolic disturbances caused by excessive lipid mobilization. Nevertheless, the above considerations demonstrate the role of fat storage in anticipation of periods of undernutrition, but also that too much fat cannot prevent body protein loss and may even inhibit behavioural adaptations that anticipate lethal depletion of body protein or metabolic disturbances.

Another aspect of adaptation to undernutrition is the long- and short-term interactions between seasonal food availability and reproduction [77]. Indeed, the longterm evolutionary adaptation is that sexual activity of some ruminants (sheep, goat, deer, etc.) is controlled by season (via photoperiod), in order to ensure that birth occurs in a favourable season (spring) and that body reserves can be replenished before the next reproductive cycle. Moreover undernutrition impairs normal activity of the hypothalamo-pituitary-gonadal axis and thus blocks the reproductive process. Interactions between season and nutrition on reproduction are probably mediated in part by leptin, the adipocyte hormone that is secreted according to a 
variety of regulating factors, including body fatness, nutritional status and day length.

Undernutrition may result not only from limitation in food supply but also from physiological increases in nutrient use, e.g. during early lactation when the mammary demand for substrates depletes the body for several weeks, despite increased intake of high quality diets. In this situation, digestion and metabolism of splanchnic tissues adapt to the high level of intake, whereas muscle and AT are mobilized to support the mammary gland activity (teleophoresis) and to ensure homeostasis. Endocrine profiles are similar to those found in underfed, non-productive animals, but with a more marked increase in $\mathrm{GH}$ secretion. Milk yield potential is, however, not achieved in the medium term ( $1-2$ months) if protein deficiency results in more than a $15 \%$ mobilization of body proteins, or if body fat content is insufficient to cover the energy deficiency.

Finally, although mechanisms for the short- and medium-term digestive and metabolic adaptations to undernutrition have been frequently studied in ruminants, there are few data from long-term trials, on the residual effects of the previous period during underfeeding-refeeding sequences (see Dulloo et al. [39] for body composition data in humans), nor on the potential interactions of endocrine signals arising from seasonal rhythms driven by photoperiodism. Studies are numerous in productive animals (i.e. compensatory growth [61] or lactation cycle) but scarce in adult animals at maintenance in extensive production systems with low food availability. From a practical point of view, a better understanding of these mechanisms will help to specify the concept of 'maintenance requirements', to improve animal husbandry in extensive conditions and to make intervention programmes in lesser developed countries more effective.

\section{ACKNOWLEDGMENTS}

We thank G.E. Lobley, J. Grizard, M. Bonnet, Y. Faulconnier, A. Ferlay and P. Nozière for helpful advices and discussions, and $Y$. Fournier and $P$. Béraud for help during the preparation of the manuscript.

\section{REFERENCES}

[1] Agabriel J., Grenet N., Petit M., Etat corporel et intervalle entre vêlages chez la vache allaitante : bilan de deux années d'enquête en exploitation, Inra Prod. Anim. 5 (1992) 355-369.

[2] Atti N., Bocquier F., Khaldi G., Thériez M., Localisation et importance des différents dépôts adipeux selon l'état corporel chez des brebis à queue grasse, Ann. Zootech. 42 (1993) 214-215.

[3] Barash I.A., Cheung C.C., Weigle D.S., Ren H., Kabigting E.B., Kuijper J.L., Clifton D.K., Steiner R.A., Leptin is a metabolic signal to the reproductive system, Endocrinology 137 (1996) 3144-3147.

[4] Bauman D.E., Vernon R.G., Effects of exogenous bovine somatotropin on lactation, Annu. Rev. Nutr. 13 (1993) 437-461.

[5] Billington C.J., Briggs J.E., Harker S., Grace M., Levine A.S., Neuropeptide $Y$ in hypothalamic paraventricular nucleus: a center coordinating energy metabolism, Am. J. Physiol. 266 (1994) R1765-R1770.

[6] Blum J.W., Schnyder W., Kunz P.L., Blom A.K., Bickel H., Schürch A., Reduced and compensatory growth: endocrine and metabolic changes during food restriction and refeeding in steers, J. Nutr. 115 (1985) 417-424.

[7] Bocquier F., Chilliard Y., Effect of severe undernutrition on body weight and fat tissue changes in dry Lacaune ewes, Ann. Zootech. 43(1994) 300.

[8] Bocquier F., Kann G., Thériez M., Relationships between secretory patterns of growth hormone, prolactin and body reserves and milk yield in dairy ewes under different photoperiod and feeding conditions, Anim. Prod. 51 (1990) 115-125.

[9] Bocquier F., Kann G., Thimonier J., Effects of body composition variations on the duration of the postpartum anovulatory period of milked ewes submitted to two different photoperiods, Reprod. Nutr. Dev. 33 (1993) 395-403.

[10] Bocquier F., Ferlay A., Chilliard Y., Effects of body lipids and energy balance on the response of plasma non-esterified fatty acids 
to a $\beta$-adrenergic challenge in the lactating dairy ewe, Proc. 14th Symposium on Energy Metabolism of Farm Animals, Newcastle, Northern Ireland, 14-20 Sept., 1997, CAB Int., 1998, pp. 167-170.

[11] Boisclair Y.R., Bell A.W., Dunshea F.R., Harkins M., Bauman D.E., Evaluation of the arteriovenous difference technique to simultaneously estimate protein synthesis and degradation in the hindlimb of fed and chronically underfed steers, J. Nutr. 123 (1993) 1076-1088.

[12] Bonnet M., Hocquette J.F., Faulconnier Y., Fléchet J., Bocquier F., Chilliard Y., Régulation nutritionnelle de l'activité lipoprotéinelipasique et de ses ARN messagers dans le tissu adipeux et le cœur chez la brebis, Nutr. Clin. Métabol. 11 (1997) 274.

[13] Bonnet M., Faulconnier Y., Bocquier F., Martin P., Chilliard Y., La photopériode et l'état nutritionnel modulent l'expression du gène spécifiant la leptine dans le tissu adipeux périrénal de brebis, Nutr. Clin. Métabol. 11 (1997) 280.

[14] Bonnet M., Faulconnier Y., Fléchet J., Hocquette J.F., Leroux C., Langin D., Martin P., Chilliard Y., Messenger RNAs encoding lipoprotein lipase, fatty acid synthase and hormone-sensitive lipase in the adipose tissue of underfed-refed ewes and cows, Reprod. Nutr. Dev. (1998) (in press).

[15] Brockman R.P., Laarveld B., Hormonal regulation of metabolism in ruminants; a review, Livest. Prod. Sci. 14 (1986) 313-334.

[16] Burrin D.G., Ferrell C.L., Britton R.A., Bauer M., Level of nutrition and visceral organ size and metabolic activity in sheep, Br. J. Nutr. 64 (1990) 439-448.

[17] Burrin D.G., Britton R.A., Ferrell C.L., Bauer M.L., Level of nutrition and visceral organ protein synthetic capacity and nucleic acid content in sheep, J. Anim. Sci. 70 (1992) 1137-1145.

[18] Butler W.R., Canfield R.W., Interrelationships between energy balance and postpartum reproduction, Cornell Nutr. Conf. 24-28 October, 1989, pp. 66-74.

[19] Butler-Hogg B.W., Wood J.D., Bines J.A., Fat partitioning in british Friesian cows: the influence of physiological state on dissected body composition, J. Agric. Sci. Camb. 104 (1985) 519-528.

[20] Casanova L., Alonso G., Moreno F.J., Some aspects of metabolic adaptations in lipid metabolism during starvation are mimicked by epinephrine in rat adipocytes, Int. J. Biochem. 22 (1990) 19-23.

[21] Cherel Y., Robin J.P., Heitz A., Calgari C., Le Maho Y., Relationships between lipid availability and protein utilization during pro- longed fasting, J. Comp. Physiol. B, 162 (1992) 305-313.

[22] Chilliard Y., Variations quantitatives et métabolisme des lipides dans les tissus adipeux et le foie au cours du cycle gestation-lactation, Reprod. Nutr. Dev. 27 (1987) 327-398.

[23] Chilliard Y., Particularités du métabolisme des lipides et du métabolisme énergétique chez le dromadaire. Options Méditerranéennes, in: Digestion, Nutrition et Alimentation du Dromadaire, Série Séminaires, 1989, vol. 2, pp. 101-110.

[24] Chilliard Y., Physiological constraints to milk production: factors which determine nutrient partitioning, lactation persistency and mobilization of body reserves, World Rev. Anim. Prod. 27 (1992) 19-26.

[25] Chilliard Y., Les adaptations métaboliques et le partage des nutriments chez l'animal en lactation, in: Martinet J., Houdebine L.M. (Eds.), Biologie de la lactation, Inserm-Inra Publ., Paris, France, 1993, pp. 431-475.

[26] Chilliard Y., Robelin J., Mobilization of body proteins by early lactating cows measured by slaughter and D20 dilution techniques, IVth Int. Symp. Protein Metabolism and Nutrition (Clermont-Ferrand), EAAP Publ. 31, Inra Publ., vol. II, 1983, pp. 195-198.

[27] Chilliard Y., Sauvant D., Morand-Fehr P., Delouis C., Relations entre le bilan énergétique et l'activité métabolique du tissu adipeux de la chèvre au cours de la première moitié de la lactation, Reprod. Nutr. Dev. 27 (1987) 307-308.

[28] Chilliard Y., Cissé M., Lefaivre R., Rémond B., Body composition of dairy cows according to lactation stage, somatotropin treatment and concentrate supplementation, J. Dairy Sci. 74 (1991) 3103-3116.

[29] Chilliard Y., Després L., Ottou J.F., Bocquier F., Responses of plasma non-esterified fatty acids to beta-adrenergic challenge in underfed or overfed non-pregnant dry cows, or in lactating cows, Proc. Soc. Nutr. Physiol. 3 (1994) 268.

[30] Chilliard Y., Doreau M., Bocquier F., Lobley G.E., Digestive and metabolic adaptations of ruminants to variations in food supply, in: Journet M., Grenet E., Farce M.H., Thériez M., Demarquilly C. (Eds.), Recent Developments in the Nutrition of Herbivores, Proc. IVth Int. Symp. on the Nutrition of Herbivores, Inra Editions, Paris, France, 1995 , pp. 329-360.

[31] Chilliard Y., Faulconnier Y., Bonnet M., Bocquier F., Mid-term effect of photoperiod on adipose tissue lipogenesis, plasma metabolites, insulin, somatotropin and prolactin in underfed-refed ewes, Proc. 14th Symposium on Energy Metabolism of Farm Animals, 
Newcastle, Northern Ireland, 14-20 Sept., 1997, CAB Int., 1998, pp. 67-70.

[32] Chilliard Y., Guerre-Millo M., Faulconnier Y., Bonnet M., Bocquier F., Effet de la photopériode et de l'état nutritionnel sur la leptinémie chez la brebis, Réunion annuelle association française d'études et de recherches sur l'obésité, Paris, 12 December 1997, p. 36.

[33] Chilliard Y., Colleau J.J., Disenhaus C., Lerondelle C., Mouchet C., Paris A., L'hormone de croissance recombinante : intérêt et risques potentiels de son utilisation pour la production laitière bovine, Inra Prod. Anim. 11 (1998) 15-32.

[34] Cirio A., Boivin R., Urea recycling from the renal pelvis in sheep: a study with $\left({ }^{14} \mathrm{C}\right)$ urea, Am. J. Physiol. (1990) F1196-F1202.

[35] Clarke I.J., Horton R.J.E., Doughton B.W., Investigation of the mechanism by which insulin-induced hypoglycaemia decreases $\mathrm{LH}$ secretion in ovariectomized ewes, Endocrinology 127 (1990) 1470-1476.

[36] Cowan R.T., Robinson J.J., McDonald I., Smart R., Effects of body fatness at lambing and diet in lactation on body tissue loss, fee intake and milk yield of ewes in early lactation, J. Agric. Sci. Camb. 95 (1980) 497-514.

[37] DiMarco N.M., Beitz D.C., Whitehurst G.B., Effect of fasting on free fatty acid, glycerol and cholesterol concentrations in blood plasma and lipoprotein lipase activity in adipose tissue of cattle, J. Anim. Sci. 52 (1981) 75-82.

[38] Doreau M., Ferchal E., Beckers Y., Effects of level of intake and of available volatile fatty acids on the absorptive capacity of sheep rumen, Small Ruminant Res. 25 (1997) 99-105.

[39] Dulloo A.G., Jacquet J., Girardier L., Autoregulation of body composition during weight recovery in human: the Minnesota Experiment revisited, Int. J. Obesity 20 (1996) 393-405.

[40] Dulphy J.P., Balch C.C., Doreau M., Adaptation des espèces domestiques à la digestion des aliments lignocellulosiques, in: Jarrige R., Ruckebusch Y., Demarquilly C., Farce M.H., Journet M. (Eds.), Nutrition des ruminants domestiques. Ingestion et Digestion, Inra Editions, Versailles, France, 1995, pp. $759-803$.

[41] Dunshea F.R., Bell A.W., Trigg T.E., Relations between plasma non-esterified fatty acid metabolism and body tissue mobilization during chronic undernutrition in goats, $\mathrm{Br}$. J. Nutr. 60 (1988) 633-644.

[42] Dunshea F.R., Bell A.W., Trigg T.E., Nonesterified fatty acid and glycerol kinetics and fatty acid re-esterification in goats during early lactation, Br. J. Nutr. 64 (1990) 133-145.

[43] Durand D., Lefaivre J., Chilliard Y., Bauchart D., Effects of food intake and milk yield on portal and hepatic vein blood flows of high yielding dairy cows in early lactation, Reprod. Nutr. Dev. 32 (1992) 505.

[44] Dyer C.J., Simmons J.M, Matteri R.L., Keisler D.H., Effects of an intravenous injection of NPY on leptin and NPY-Y1 receptor mRNA expression in ovine adipose tissue, Dom. Anim. Endocrinol. 14 (1997) 325-333.

[45] Ebling F.P.J., Wood R.I., Karsch F.J., Vannerson L.A., Suttie J.M., Bucholtz D.C., Schall R.E., Foster D.L., Metabolic interfaces between growth and reproduction. III- Central mechanisms controlling pulsatile luteinizing hormone secretion in the nutritionally growthlimited female lamb, Endocrinology 126 (1990) 2719-2727.

[46] Ferlay A., Chilliard Y., Effects of $\beta$ - et $\beta 1$-, and $\beta 2$-adrenoceptor agonist infusion on plasma non-esterified fatty acids in non-pregnant, non-lactating, underfed cows, Ann. Zootech. 44 (suppl.) (1995) 299.

[47] Ferlay A., Chilliard Y., Sala A.M., Durier C., Bocquier F., Somatotropin treatment does not effect nonesterified fatty acid response to adrenergic injections in underfed or overfed nonlactating cows, J. Nutr. 126 (1996) 945-954.

[48] Ferlay A., Charret C., Galitzky J., Berlan M., Chilliard Y., Effets de la perfusion d'agonistes $\beta$-, $\beta 2$ - ou $\beta 3$-adrénergiques ou d'adrénaline sur la lipolyse in situ du tissu adipeux sous-cutané ovin, Nutr. Clin. Métabol. 11 (1997) 302

[49] Ferro-Luzzi A., Petracchi C., Kuriyan R., Kurpad A.V., Basal metabolism of weightstable chronically undernourished men and women: lack of metabolic adaptation and ethnic differences, Am. J. Clin. Nutr. 66 (1997) 1086-1093.

[50] Freetly H.C., Ferrell C.L., Jenkins T.G., Goetsch A.L., Visceral oxygen consumption during chronic feed restriction and realimentation in sheep, J. Anim. Sci. 73 (1995) 843-852.

[51] Fröhli D., Blum J.W., Effects of fasting on blood plasma levels, metabolism and metabolic effects of epinephrine and norepinephrine in steers, Acta Endocrinol. 118 (1988) 254-259.

[52] Gagliostro G., Chilliard Y., Duodenal rapeseed oil infusion in early and midlactation cows. 4. In vivo and in vitro adipose tissue lipolytic responses, J. Dairy Sci. 74 (1991) 1830-1843.

[53] Galyean M.L., Owens F.N., Effects of diet composition and level of feed intake on site 
and extent of digestion in ruminants, in: Tsuda T., Sasaki Y., Kawashima R. (Eds.), Physiological Aspects of Digestion and Metabolism in Ruminants, Proc. 7th. Int. Symp. Ruminant Physiology, Acad. Press, San Diego, USA, 1991, pp. 483-514.

[54] Gibb M.J., Ivings W.E., Dhanoa M.S., Sutton J.D., Changes in body components of autumncalving Holstein-Friesian cows over the first 29 weeks of lactation, Anim. Prod. 55 (1992) $339-360$.

[55] Gluckman P.D., Breier B.H., Davis S.R., Physiology of the somatotropic axis with particular reference to the ruminant, J. Dairy Sci., 70 (1987) 442-466.

[56] Grimaud P., Doreau M., Effect of extended underfeeding on digestion and nitrogen balance in non-lactating cows, J. Anim. Sci. 73 (1995) 211-219.

[57] Grimaud P., Richard D., Kanwé A., Durier C., Doreau M., Effect of undernutrition and refeeding on digestion in Bos taurus and Bos indicus under tropical environment, Anim. Sci. (in press).

[58] Gruffat D., Durand D., Chilliard Y., Williams P., Bauchart D., Hepatic gene expression of apolipoprotein B100 during early lactation in underfed, high producing dairy cows, $J$. Dairy Sci. 80 (1997) 657-666.

[59] Gunn R.G., The influence of nutrition on the reproductive performances of ewes, in: Haresign W. (Ed.), Sheep Production, Butterworths, London, 1983, pp. 99-110.

[60] Harris P.M., Lee J., Sinclair B.R., Treloar B.P., Gurnsey M.P., Effect of food intake on energy and protein metabolism in the skin of Romney sheep, Br. J. Nutr. 71 (1994) 647-660.

[61] Hogg B.W., Compensatory growth in ruminants, in: Pearson A.M., Dutson R. (Eds.), Growth Regulation in Farm Animals. Advances in Meat Research, vol. 7, Elsevier Applied Science, London, UK, 1991, pp. 103-104.

[62] Houseknecht K.L., Bauman D.E., Carey G.B., Mersmann H.J., Effect of bovine somatotropin and food deprivation on $\beta$-adrenergic and $A_{1}$ adenosine receptor binding in adipose tissue of lactating cows, Dom. Anim. Endocrinol. 12 (1995) 325-336.

[63] Ingle D.L., Bauman D.E., Mellenberger R.W., Johnson D.E., Lipogenesis in the ruminant: effect of fasting and refeeding on fatty acid synthesis and enzymatic activity of sheep adipose tissue, J. Nutr. 103 (1973) 1479-1488.

[64] Johnson C.L., Johnson D.E., Rumpler W.V., Source and level of alimentation effects on visceral organ mass of fat steers, in: Moe P.W., Tyrrell H.F., Reynolds P.J. (Eds.), Energy Metabolism of Farm Animals, Row- man and Littlefield, Totowa, USA, 1987, pp. 50-53.

[65] Journet M., Champredon C., Pion R., Vérité R., Physiological basis of the protein nutrition of high producing cows. Critical analysis of the allowances, in: Arnal M., Pion R., Bonin D. (Eds.), Proc. 4th Int. Symp. Protein Metabolism and Nutrition, Clermont-Ferrand, I, Inra Publ., Versailles, France, 1983, pp. 433-447.

[66] Kabré P., Doreau M., Michalet-Doreau B., Effects of underfeeding and of fish meal supplementation on forage digestion in sheep, $J$. Agric. Sci. Camb. 124 (1995) 119-127.

[67] Ku-Vera J.C., MacLeod N.A., Ørskov E.R., Energy exchanges of cattle nourished by intragastric infusion of nutrients, in: van der Honing Y., Close W.H. (Eds.), Proc. 11 th Symp. Energy Metabolism of Farm Animals, Lunteren, 18-24 Sept., Pudoc, Wageningen, the Netherlands, 1989, pp. 271-274.

[68] Larbaud D., Debras E., Taillandier D., Samuels S.E., Temparis S., Champredon C., Grizard J., Attais D., Euglycemic hyperinsulinemia and hyperaminoacidemia decrease skeletal muscle ubiquitin mRNA in goats, Am. J. Phys. 271 (1996) E505-E512.

[69] Le Houérou H.N., Recherches expérimentales sur la tolérance du mouton barbarin à l'inanition et la restriction alimentaire, in: Le Floc'h E., Grouzis M., Cornet A., Bille J.C. (Eds.), L'Aridité: Contrainte au développement, Orstom éditions, Paris, France, 1992, pp. 369-385.

[70] Lindsay D.B., Metabolism of the portaldrained viscera, in: Forbes J.M., France J. (Eds.), Quantitative Aspects of Ruminant Digestion and Metabolism, CAB International, Wallingford, Oxon, UK, 1993, pp. 267-289.

[71] Liu S.M., Lobley G.E., MacLeod N.A., Kyle D.J., Chen X.B., Ørskov E.R., Effects of longterm protein excess or deficiency on wholebody protein turnover in sheep nourished by intragastric infusion of nutrients, Br. J. Nutr. 73 (1995) 829-839.

[72] Lobley G.E., Harris P.M., Skene P.A., Brown D., Milne E., Calder A.G., Anderson S.E., Garlick P.J., Nevison I., Connell A., Response in tissue protein synthesis to sub- and supramaintenance intake in young growing sheep: comparison of large-dose and continuousinfusion techniques, Br. J. Nutr. 68 (1992) 373-388.

[73] Lobley G.E., Connell A., Milne E., Newman, A.M., Ewing T.A., Protein synthesis in splanchnic tissues of sheep offered two levels of intake, Br. J. Nutr. 71 (1994) 3-12.

[74] Lomax M.A., Baird G.D., Blood flow and nutrient exchange across the liver and gut of 
the dairy cow. Effects of lactation and fasting, Br. J. Nutr. 49 (1983) 481-496.

[75] McDowell G.H., Hormonal control of glucose homoeostasis in ruminants, Proc. Nutr. Soc. 42 (1983) 149-167.

[76] Michalet-Doreau B., Martin C.. Doreau M., Optimisation de la digestion des parois végétales dans le rumen : quantification des interactions digestives, Renc. Rech. Ruminants 4 (1997) 103-112.

[77] Ortavant R., Bocquier F., Pelletier J., Thimonier J., Volland-Nail P., Seasonality of reproduction in sheep and its control by photoperiod, Aust. J. Biol. Sci. 41 (1988) 69-85.

[78] Ortigues I., Adaptation du métabolisme énergétique des ruminants à la sous-alimentation. Quantification au niveau de l'animal entier et de tissus corporels, Reprod. Nutr. Dev. 31 (1991) 593-616.

[79] Ortigues I., Doreau M., Responses of the splanchnic tissues of ruminants to changes in intake: absorption of digestion end-products, tissue mass, metabolic activity and implications to whole animal energy metabolism, Ann. Zootech. 44 (1995) 321-346.

[80] Ortigues I., Durand D., Adaptation of energy metabolism to undernutrition in ewes. Contribution of portal-drained viscera, liver and hindquarters, Br. J. Nutr. 73 (1995) 209-226.

[81] Panaretto B.A., Body composition in vivo. VI. The composition of ewes during a prolonged undernutrition, Austr. J. Agric. Res. 15 (1964) 771-787.

[82] Pethick D.W., Lindsay D.B., Metabolism of ketone bodies in pregnant sheep, Br. J. Nutr. 48 (1982) 549-563.

[83] Pethick D.W., Dunshea F.R., Fat metabolism and turnover, in: Forbes J.M., France J. (Eds.). Quantitative Aspects of Ruminant Digestion and Metabolism, CAB International, Wallingford, Oxon, UK, 1993, pp. 291-311.

[84] Rayssiguier Y., Mazur A., Rémond B., Chilliard Y., Gueux E., Influence de l'état corporel au vêlage et du niveau d'alimentation en début de lactation sur la stéatose hépatique chez la vache laitière, Reprod. Nutr. Dev. 26 (1986) 359-360.
[85] Reid I.M., Collins R.A., Baird G.D., Roberts C.J., Symonds H.W., Lipid production rates and the pathogenesis of fatty liver in fasted cows, J. Agric. Sci. Camb. 93 (1979) 253-256.

[86] Rhind S.M., Leslie I.D., Gunn R.G., Doney J.M., Plasma FSH, LH, prolactin, progesterone profiles of Cheviot ewes with different levels of intake before and after mating, and associated effects on reproductive performance, Anim. Reprod. Sci. 8 (1985) 301-313.

[87] Robelin J., Agabriel J., Malterre C., Bonnemaire J.F., Changes in body composition of mature dry cows of Holstein, Limousin and Charolais breeds during fattening. I. Skeleton, muscles, fatty tissues and offal, Livest. Prod. Sci. 25 (1990) 199-215.

[88] Rohr K., Lebzien P., Present knowledge of amino acid requirements for maintenance and production, Proc. 6th Int. Symp. Protein Metabolism and Nutrition, Herning, Denmark, vol. 1, 1991, pp. 127-137.

[89] Sainz R.D., Bentley R.E., Visceral organ mass and cellularity in growth-restricted and refed beef steers, J. Anim. Sci. 75 (1997) 1229-1236.

[90] Shetty P.S., Physiological mechanisms in the adaptive response of metabolic rates to energy restriction, Nutr. Res. Rev. 3 (1990) 49-74.

[91] Taylor St.C.S., Murray J.L., Effect of feeding level, breed and milking potential on body tissues and organs of mature, non-lactating cows, Anim. Prod. 53 (1991) 27-38.

[92] Tesseraud S., Grizard J., Debras E., Papet I., Bonnet Y., Bayle G., Champredon C., Leucine metabolism in lactating and dry goats: effect of insulin and substrate availability, Am. J. Physiol. 265 (1993) E402-E413.

[93] Vernon R.G., Effects of diet on lipolysis and its regulation, Proc. Nutr. Soc. 51 (1992) $397-408$.

[94] Wiktorsson H., General plane of nutrition for dairy cows, in: Broster W.H., Swan H. (Eds.), Feeding Strategy for the High Yielding Dairy Cow, E.A.A.P. Publ. no. 25, Granada Ltd, 1979, pp. 148-170.

[95] Zammit V.A., Ketogenesis in the liver of ruminants. Adaptations to a challenge, J. Agric. Sci. Camb. 115 (1990) 155-162. 